\title{
ANALYSIS OF THE PERFORMANCE DETERMINANTS OF THE ALLIANCE STRATEGY: EMPIRICAL STUDY ON LEARNING GUIDANCE IN DKI JAKARTA
}

\author{
Maikel Rudianto ${ }^{1}$ \\ ${ }^{1}$ Faculty of Economics, Universitas Negeri Jakarta \\ Jakarta, Indonesia \\ maikelrudianto@gmail.com \\ Unggul Purwohendi ${ }^{2}$ \\ ${ }^{2}$ Faculty of Economics, Universitas Negeri Jakarta \\ Jakarta, Indonesia \\ upurwohedi@gmail.com \\ Budi Santoso ${ }^{3}$ \\ ${ }^{3}$ Faculty of Economics, Universitas Negeri Jakarta \\ Jakarta, Indonesia \\ rawdo2003@gmail.com
}

\begin{abstract}
The alliance strategy is one solution to the speed of competition in the business or business world. Strategic alliances are cooperative strategies in the form of partnerships that help unify each party's strengths to mutually benefit in the form of benefits and long-term competitiveness in the market. The alliance's strategy can be assessed as successful or not by measuring the strategic alliance's performance because the most commonly used alliance measure is performance. Whether or not an alliance strategy adopted by a company is healthy is to evaluate its alliance strategy's implementation. This research was conducted using non-sampling or census methods as many as 132 (one hundred and thirty-two) branches in DKI Jakarta in one of the companies in the education sector originating from Japan and developing an alliance strategy in Indonesia. Data collection was carried out using a questionnaire and met with the owners or direct branch leaders.
\end{abstract}

From this study, it is concluded that Goodwill trust, Competence Trust, and Tangible \& Intangible Resources Sharing positively influence the performance of the alliance 
strategy. Also, Tangible \& Intangible Resources Sharing as an intervening variable can mediate the relationship between Goodwill trust and Competence Trust on the alliance's strategy's performance.

Keywords: Goodwill Trust, Competence Trust, Tangible \& Intangible Resources Sharing

\section{INTRODUCTION}

Many companies that develop into multinational and international companies force companies to collaborate rather than compete with a much bigger goal. According to Mandal in Kinderis \& Jucevičius (2015), the strategic alliance may be considered normal; for some companies, it intends to plan future activities to achieve strategic goals. Strategic alliance refers to a company's partnership to achieve common goals and is therefore indicative of cooperation between participants. Also, Andrew C. Inkpen, in Lasserre (2012), adds that the increasingly crucial collaborative goal in today's tight competition is speed. This shows that strategic alliances are a choice of business strategies that have a rate in business competition. When given a choice between internal development and alliances, many companies choose alliances to allow faster strategy implementation.

The formation of strategic alliances based on motives is a sequential process that includes business strategy and market research, product portfolio assessment, evaluation of company (partner) strengths and opportunities, preparation to satisfy market needs, and implementation of company strengths and opportunities in potential activities (Kinderis \& Jucevičius, 2015). Alliances can be judged successful or not by measuring the performance of these strategic alliances; according to Jim Bamford and David Ernst in Mckinsey \& Company Finance \& Number (2006), to get a better grip on performance, companies must develop a more structured approach to evaluate the health of their alliances.

It can be understood that a good alliance will be measured through a good alliance performance. To calculate the account's success is not easy, so it takes the factors that measure the performance of the alliance. Although it is difficult to measure and experience some conceptual treatments, trust has become a core concept of alliances 
(Lasserre, 2012). So it can be said that in measuring the performance of strategic alliances or strategic alliances arrangements, trust or trust becomes a variable that can be a tool to measure the quality of strategic alliance performance. Although, in general, it has been argued that confidence improves alliance performance, Yan \& Gray (1995) suggested that performance may have a feedback effect on trust. Poor performance can lead to mistrust among partners, which in turn leads to poor long-term alliance performance. We analyze trust in two dimensions - trust in goodwill and trust incompetence (Brattström, Löfsten, \& Richtnér, 2012).

The first factor in measuring strategic sense performance is trust. According to Mohr \& Puck, 2013 in research on the relationship of trust with performance in strategic alliances (SA), which is expanded with traditional research and focuses on the influence of trust on the performance of strategic alliance (SA) needs that must be complemented by more explicit recognition and analysis of the role of the alliance. Strategic (SA) on performance developed with confidence. Goodwill Trust is emotional and rooted in affective conditions interested in partners' well-being (Lewis, 1985); meanwhile, competency belief is a rational evaluation of a partner's ability to carry out obligations (Rempel \& Holmes, 1989). In a previous study, Dyer \& Chu (2011) stated that previous alliance research had used dimensional unions or a global measure of trust or only emphasized Goodwill Trust's dimensions. Meanwhile, the competence of faith is not considered in empirical alliance research; or other words, the multi-dimensionality of alliance trust has been largely ignored (Brattström et al., 2012).

According to Mohr \& Puck (2013), trust, environmental dynamism, size, strategic control, and complementary influence the performance of strategic alliances. Also (Mohr \& Puck, 2013) added that there are two directions, the causal relationship between trust and performance in strategic alliances (SA), namely, the level of trust in strategic alliances (SA) has a positive influence on the performance of strategic alliances (SA) and the level of performance. A strategic alliance (SA) positively influences the level of trust in a strategic alliance (SA). So it can be concluded in previous research that trust is one of the measuring tools to see strategic alliances' performance. The second factor in measuring strategic alliances' performance is a variety of resources (shared resources). Sharing shared resources (both tangible and intangible) from partners contributes to the 
performance of a company's alliance, focusing on multiplying strategic opportunities and synergies in building individuals, such as achieving grander scale and potential to be able to keep up with the development of new knowledge and technology. (Jiang, Jiang, Cai, \& Liu, 2015).

Based on previous research, it can be concluded that in measuring strategic alliance performances, resource sharing can be used (tangible \& Intangible Resources Sharing). This shows that in previous studies sharing resources (resources shared) is a factor in measuring strategic alliance performance. Through various efforts, the motivation of this research is based on previous research where this research tries to contribute to the scientific literature related to three things, and the first is how goodwill trust can influence the performance of alliance strategies; second, how does competence trust affect the performance of alliance strategies and the third is how Tangible \& Intangible have an influence on the alliance's performance as well as being a mediator that strengthens the impact of Goodwill trust and Competence trust on the alliance's performance.

\section{LITERATURE REVIEW}

\section{Strategic Alliances Performance}

The alliance is defined as "A process in which participants are willing to modify their basic business practices to reduce duplication and waste while facilitating increased performance." Whipple, Frankel, \& Daugherty, (2002). Alliance performance is one of the most studied alliance literature topics ( McCutchen, Swamidass, \& Teng, 2007). The problem related to alliance performance is the instability of the alliance. It has been found that, despite all the recognized benefits, alliances are highly volatile. Alliance instability refers to an unexpected termination or significant restructuring of the alliance (McCutchen et al., 2007). To see/avoid alliance instability, it is necessary to understand the alliance's performance. According to (McCutchen et al., 2007), there are three theories to understand strategic alliances' performance, namely transaction cost theory, resourcebased view theory, and social networking theory.

Understanding the performance of the alliance in the theory of economic transaction costs puts forward the idea of opportunism, or pursues self-interest with the deception of opportunistic behavior, alliance partners need to use a variety of coordination 
mechanisms that involve "high expenditures for drafting, negotiating, monitoring and enforcing contingent claim contracts; namely, expenses collectively are referred to as transaction costs. The alliance's high transaction costs are responsible for the alliance's performance and can adversely affect the alliance or instability (Park-Russo-Mgmt-Sci1996; McCutchen et al., 2007). This explains that The alliance will require high costs if each party's trust is low; this is because each party must protect itself from the loss of an alliance with rules or contracts legally so that it will avoid risks that have an impact on the performance of the alliance.

The second approach in understanding alliance performance is related to the company's resource-based view (Barney, 1991; McCutchen et al., 2007). According to this view, alliances create value when they pool resources from various parties and then pursue opportunities outside the firm's capabilities (Eisenhardt \& Schoonhoven, 1996; McCutchen et al., 2007). Thus, alliance performance depends on the specific alignment of resources between the alliance partner, and the alliance will remain stable as long as the partner continues to have the desired exchange of resources. This view focuses on partner selection and learning as the main determinants of alliance success (McCutchen et al., 2007). In this approach, the alliance's performance will have a good impact if it can select alliance partners with potential resources and become the alliance's performance booster with progress as expected.

Understanding the performance of the third alliance is with social networking theory which pays more attention to the network in which the company operates. Alliance activity is influenced by network characteristics (such as homogeneity and structural holes) and its network positioning based on concepts such as centrality, connectivity, and direct and indirect relationships. For example, alliances between/between companies that occupy a central position and with successful previous ties with other companies are more likely to perform well (Location \& Formation, 2015; Baum, Tony, \& Silverman, 2000; Powell, Koput, \& Smith-Doerr, 2006; McCutchen et al., 2007). The alliance's performance will run well and be successful by forming an alliance through a network or networking that has been done before. Moreover, the collaboration that is carried out produces results as expected and is successful, so alliances will tend to be formed with old partners, and the performance of the alliances will run better because they are created 
based on cooperation from past experiences or in other words they already know each other.

\section{Trust}

Many factors can influence an alliance's success, and partner selection emerges as one of the most influential. Previous studies on alliances present a general model that assumes the factors (e.g., trust, commitment, complementarity, financial rewards) that drive partner attractiveness and, in turn, the likelihood of selection are consistent across different projects and alliance situations (Shah \& Swaminathan, 2008). As stated in the previous discussion, trust is one of the determining factors for the alliance's performance's success. Trust is an active and representative element of social capital theory. Trust is a subject of widespread concern in social capital theory (Stoltz-Andersen, 2014). Although it is difficult to measure and experience some conceptual treatments, trust has become a core concept of alliances (Lasserre, 2012).

Perceptions of trust can also increase the perception that partners will be willing and able to fulfill role obligations and try to maximize mutual benefits in the relationship (Publications, 2019; Shah \& Swaminathan, 2008). Shah \& Swaminathan (2008) said that trust could help overcome potential opportunism; its importance in the attractiveness pair should be more significant when the uncertainty in the alliance is high, and consequently, the risk of the initiative is greater. So it can be concluded that the role of trust is the primary value in the performance of the alliance to minimize the negative side of the alliance relationship, such as the opportunistic attitude of each partner. As defined, trust can be categorized into two types mentioned above: goodwill trust and competency trust. Specifically, goodwill trust is generated by partner virtue, integrity, and goodwill, while competence is the belief that a partner has sufficient resources and abilities to meet the requirements of cooperation (Lui \& Ngo, 2004; Patzelt \& Shepherd, 2008).

According to Lui \& Ngo (2004), that trust in goodwill is related to relational risk and refers to the expectation that the partner intends to fulfill their role in the relationship. These expectations are based on the perceptions and reciprocity of certain key personnel who can be seen as trustees or people with whom the organization has ties. In this study, we measured goodwill beliefs as personal beliefs. Competency belief refers to the 
expectation that partners can fulfill their role. This is related to performance risk, and we measure it as a contractor's resources and reputation.

\section{Resource Shared (Tangible and Intangible Resource)}

Based on the previous study, understanding the alliance's performance uses a resourcebased view (RBV) theory. According to a resource-based view of the alliance that focuses on creating pooled resources' value (Das \& Teng, 2000). Following Lambe et al. in (Wittmann, Hunt, \& Arnett, 2009), that a business alliance is a collaborative effort between two or more companies in which companies pool their resources in an effort to achieve mutually compatible goals that they cannot reach quickly alone. Focusing exclusively on the resource-based view of strategic alliances, Eisenhardt and Schoonhoven in Das \& Teng (2000) find that a more critical alliance is likely to be formed when the two companies are in a vulnerable strategic position, when they need resources or when they are in a solid social position that is when they have valuable resources to share.

The resource-based view considers strategic alliances and mergers/acquisitions as strategies used to access other companies' resources to accumulate competitive advantages and values that are not available to the company (Das \& Teng, 2000). The alliance benefits arise from the exchange of valuable resources contributed by each partner (Wittmann et al., 2009). Based on the RBV theory, the current study proposes that the sharing of resources between partners is a critical cooperative action in an alliance, perhaps a mechanism of intervention between trust and alliance performance. Resource sharing here refers to the reciprocal exchange of company-specific resources between alliance partners. Based on resource classification, two types of resource sharing are distinguished in our study: sharing tangible resources and sharing intangible resources. As implied by the resource-based view, tangible and intangible resources differ in the following respects: (1) tangible resources are physical, while intangible resources are not, and (2) tangible resources are easily transmitted, whereas intangible resources are intangible. (Darnall, Henriques, \& Sadorsky, 2010; (Das \& Teng, 2000). This is reinforced by (Vatne, 2017) saying a resource-based view from the company side that business organizations as a collection of resources are understood as a set of tangible and intangible assets, which are semi-permanently linked to the company. According to T Das 
$\&$ Teng (2000), Tangible resource shared (tangible resources consist of physical resources such as equipment and financial assets. Meanwhile, intangible resources) consists of a single contract for government projects ( examples of patents and the like), Organizational resources (e.g., culture) (management skills) and Technological and managerial resources (technological and managerial resources).

Goodwill Trust and Alliance Performance.

According to Roy, Sivakumar, \& Wilkinson (2004) (Jiang et al., 2015), research on manufacturing companies in China found that goodwill trust tends to facilitate cooperative relationships and directly improve alliance performance. When perceived a higher level of trustworthiness in goodwill, the alliance firms are more likely to value interactions in the partnership and interact more frequently. This is also reinforced by (Zaheer, McEvily, \& Perrone, 1998) that goodwill trust tends to reduce the scope, intensity, and frequency of dysfunctional conflicts, which minimize compliance and cost coordination, ultimately increasing alliance performance.

W. Li \& Veysel (2013), in their research on the biopharmaceutical industry and electronic information industry, also stated that there is a positive correlation between goodwill trust partners and the performance of alliance strategies. This is because, in this kind of trust relationship, it is quite possible that both parties focus on long-term benefits, rather than using short-term opportunistic behavior and to resolve potential injustices (Li \& Veysel, 2013). Also, according to Sako (1998) in research conducted by Green (2003) on oil companies that have allied for three years, it is stated that goodwill trust will have a substantial impact on performance because it can offer goodwill trust and is above the formal contract government structure or hierarchies are continuous learning and improvement, not just making transaction cost savings.

According to Krishnan, Rekha (Simon Fraser University, Burnaby, BC, Martin, Xavier. (Tilborg University, Tilburg, \& Noorderhaven, Niels G. (Tilborg University, Tilburg, 2006), that trust in goodwill will be positively associated with alliance performance because it can at the same time reducing the cost of cooperation and increasing the benefits of cooperation. On the one hand, goodwill trust must reduce the cost of ex-ante and ex-post cooperation, which is negatively related to the performance of the alliance. Trust in Competence and Alliance Performance. 
According to (Patzelt \& Shepherd, 2008), with a trust alliance with a high level of competence, according to managers, it is assumed that partners can meet expectations. Therefore, the alliance's current bad performance is more likely to be associated with exogenous anomaly conditions than partners. To the extent that the manager views this exogenously as provisional, he will believe that joint efforts with competent partners and alliance goals can be achieved. Thus, although the current alliance may appear below the aspirations that managers had when the alliance was initiated, managers can quickly adjust their aspirations to their present low-performance state (Greve, 2002) and 'up' what is believed to be a temporary decline in performance. The likelihood that the alliance manager decides to stick with the alliance's poor performance may increase competency confidence. This shows that there is a relationship between Competence Trust and alliance performance.

According to (Jiang et al., 2015), research on manufacturing companies in China found that competency confidence would be positively related to alliance performance. Belief incompetence is an important foundation of alliance performance for several reasons. First, belief in partner competence can reduce firm fears that focus on perceived performance risk, which is rooted in "external factors" such as intense industrial competition, policy changes, and fluctuations in demand (Senguin \& Wasti, 2007). Competency confidence enables all players to perform more technically complicated tasks when working together, resulting in better alliance performance (Lumineau \& Malhotra, 2011). Second, placing greater trust in partner competencies makes the firm more confident that the alliance's goals will be realized in turbulent environments (Doz \& Hamel, 1998, chap. 5).

According to W. Li \& Veysel (2013), in their research on the biopharmaceutical industry and electronic information industry, it is also stated that a low level of competency confidence has a positive effect on alliance performance. Still, a high level of competency confidence has a negative impact on the performance of the alliance. The relationship between goodwill trust, competency trust, and alliance performance are stronger in an alliance under higher potential competition between partners and weaker under lower potential competition. This is also reinforced by Das \& Teng (Paik, 2005), saying that competence trust is "the expectation of ability, expertise," and "technically competent role 
performance," according to strategic alliance partners. So it can be concluded that Competence Trust has an impact on the performance of alliances or alliances performance. Shared Resources (Tangible and Intangible) and Alliance Performance.

According to (Jiang et al., 2015), research on manufacturing companies in China found that the division of (a) tangible and (b) intangible resources has a positive effect on alliance performance. This is also reinforced by (Chang 2008) that scholars take advantage of a resource-based view and find that resource sharing between strategic business units (SBU) positively affects firm performance.

As implied by the resource-based view, namely Das \& Teng (2000), shared resources (both tangible and intangible) from partners contribute to the performance of the corporate alliance focus by multiplying strategic opportunities and value synergies that are not available to an assertive individual, such as achieve a larger scale and more significant potential for developing new knowledge and technology (Lansing, Collins, \& Wiley, 2007; Wittmann et al., 2009). Then according to Wittmann et al. (2009), it is reaffirmed that in particular, the reduction in resource sharing is indicated because one party may not want to provide resources to share, and this indicates unreliability in the relationship or a lack of necessary resources. This can severely limit the development of the alliance, which will be detrimental to the two performance partners' alliance. Conversely, a fair share of both tangible and intangible resources leads to better alliance performance.

Also, according to (Van Wijk, Jansen, \& Lyles, 2008), consistent with this logic, scholars have found that transferring knowledge, a specific type of intangible resource, leads to improved alliance performance.

Goodwill Trust and Resources Sharing.

Based on social capital theory, we argue that trust goodwill positively affects resource sharing among partners. First, in high good faith conditions, allied companies will be happy to share and receive resources from one another (Brattström, Löfsten, \& Richtnér, 2012). This happens because 1) they may feel confident that they will and are not being taken advantage of by partners; and (2) encouragement of goodwill and broad communication between alliance partners to stimulate a more positive social exchange climate (Hu \& Bettis, 2014; Lópezlira, 2015). Such a partnership climate creates a greater 
willingness in corporate alliances to depend on each other to share resources at the right time and way (Lumineau \& Malhotra, 2011).

Second, good working relationships fostered by goodwill trust reduce the potential for monitoring and examining costs associated with sharing resources (J. H. Dyer \& Chu, 2003). As in research conducted by Shou, Guo, Zhang, \& Su (2011) regarding Guanxi (literally, interpersonal relationships or connections) are the lifeblood of business in China, this study is aimed at investigating the consequences, especially in the Chinese market, where it is found that Guanxi is utilitarian in developing friendships to share resources in the business community. The result is that goodwill trust is positively related to guanxi agents' behavior in the Chinese marketing channel. This shows that goodwill trust has a positive relationship with sharing resources through the guanxi mechanism.

Ndofor, Sirmon, \& He (2011) found evidence that good faith-based trust is positively related to increasing information sharing in supplier-buyer relationships. According to Galbreath (2005), relatively simple communication mechanisms involving written documents and private conversations can be guaranteed by the trust that goodwill is sufficient to share real resources. As such, we argue that the belief in goodwill will facilitate resource sharing.

Relationship Between Competence Trust and Resources Sharing.

According to Krause, Handfield, \& Tyler (2007), with higher competency levels of trust, alliance firms are more likely to share valuable resources with each other because they believe that their partners can utilize resources to create synergies. It is made clear by Jiang et al. (2015) that companies will expect that partners they believe are competitors who are not only able to share valuable resources effectively, and they are also able to increase shared resources to create shared value and increase efficiency of the alliance. In this case, place trust in the partner's capacity to both differentiate/identify useful resources and reframe the initial resources to share comfort or effectively utilize the resources together and ensure that resource sharing is carried out. According to Jiang et al. (2015), in a study of manufacturing companies in China, they found that the sharing of intangible resources is more substantial with trust competencies than sharing tangible resources. It is made clear by Hitt (2001) that competency beliefs tend to be more effective for intangibles than for sharing tangible resources. In particular, given their difficult 
nature to move, intangible resources appear to be more susceptible to uncertainty and errors when distributed. Then Jiang et al. (2015) also explain more fully that the two interactions arise from competency beliefs and the ability-based nature of competency confidence encourages a more intangible sharing of resources.

Conversely, trust competence can play a relatively limited role in sharing tangible resources such as financial capital and equipment, whose value can be verified through more uncomplicated communication and interaction with less expertise. Therefore, when comparing the sharing of tangible resources with the sharing of intangible resources, it may depend little or less on competency confidence.

\section{Mediating Effects of Resource Sharing}

Tangible and Intangible Resources Sharing between Goodwill Trust and Competence Trust with Alliance Performance.

According to Gulati \& Singh in Krishnan, Rekha (Simon Fraser University, Burnaby, BC et al., (2006) states that the level of interdependence in alliances increases with the importance and extent of the resources shared between partners and the overlap that results in the division of labor between (e.g., the resulting shared responsibility for a number of tasks) whereas alliances that are defined as sharing production facilities usually have only weak interdependence effects. Or in other words, the positive relationship between trust and alliance performance is more substantial in alliances with a high degree of interdependence than alliances with low interdependence (Krishnan, Rekha (Simon Fraser University, Burnaby, BC et al., 2006). We can conclude that the effect of trust on alliance performance is highly dependent on the level of resource sharing undertaken. As is well known, according to Das \& Teng (2000), Tangible resources are shared (tangible resources consisting of physical resources such as equipment and financial assets. Also, in previous research, there is a classification of interdependence into three strategic reasons that require limited coordination: sharing costs (for example, shared material), sharing of production facilities, and sharing of financial resources (Krishnan, Rekha (Simon Fraser University, Burnaby, BC et al., 2006). This suggests that Tangible resource shared plays a role in strengthening trust in alliance performance.

According to Jiang et al. (2015), it is explained in detail that research on manufacturing companies in China found that sharing of tangible resources is more strongly associated 
with trust in goodwill than sharing of intangible resources. So that conceptually, it can be linked that sharing of resources influences the existence of goodwill trust.

According to Jiang et al. (2015), a study of manufacturing companies in China found that the performance of solid alliances may be misattributed to trust than practical cooperative actions such as sharing resources between partners, which means that some things in the alliance prefer effective action than a collaboration rather than believing the values of trust. So this is one possible explanation for the reason why alliances have experienced the same level of confidence variation in alliance performance. Thus, it can be concluded that resource sharing mediates the relationship between trust and alliance performance. Tangible \& Intangible Resources Sharing between Competence Trust and Alliance Performance.

According to Jiang et al. (2015), trust (goodwill and competence) and sharing of resources (tangible and intangible), as well as sharing resources and alliance performance. It can be concluded that the path from trust to alliance performance may also be indirect. In particular, trust only establishes the basis for a superior alliance outcome; meanwhile, it is through sharing tangible and intangible resources that the value of trust can be fully realized for the alliance company.

This is in line with Levin, Cross, \& Abrams (2002) that competence trust guarantees efficient resource sharing between allied companies. That is, strong alliances that trust their partners' competence and abilities are more likely to listen to, absorb, and take action on desired resources (Levin \& Cross, 2004) —also emphasized by Krishnan, Rekha (Simon Fraser University, Burnaby, BC et al., 2006) that high interdependence in alliances requires partners to share intensive knowledge that is valuable resources, exposing each other.

When exchange relationships are characterized by trust, firms' access to external knowledge increases. They can integrate it with their existing resources and capabilities innovatively and efficiently to generate sustainable competitive advantage and improve their performance strategy (Jain, Khalil). Johnston, \& Cheng, 2014). So it is expected that an exchange of relationships characterized by a high level of trust will create intangible resources for the company. 


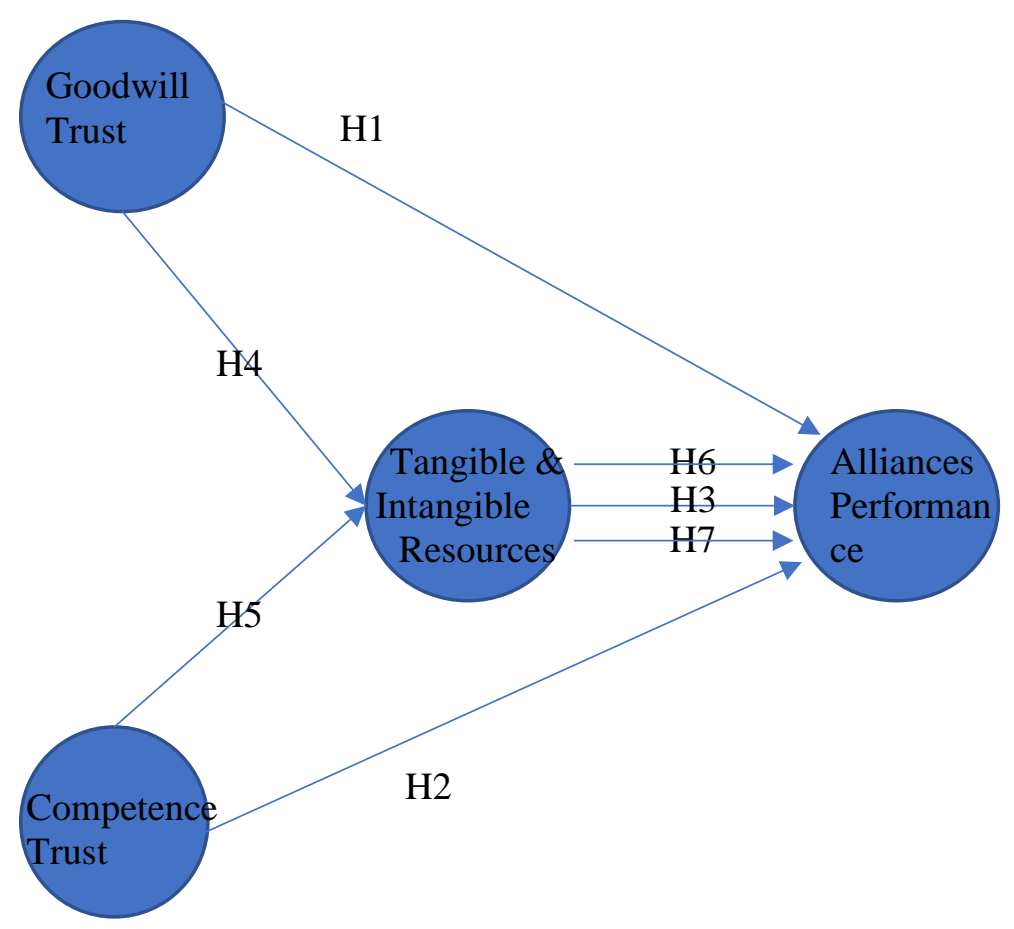

Figure 1. Research Framework

\section{RESEARCH METHOD}

This research was conducted on companies in the service sector or, more precisely, in the field of education in the Jakarta area with a non-sampling or census method of 132 (one hundred and thirty-two) branches in Jakarta, so that the research analysis used the Partial Least Square (PLS) model which is one of the alternative methods. From Structural Equation Modeling (SEM). The research method used in this research is quantitative research. This study is a research that uses primary data which presents hypothesized relationships between existing constructs to be able to explain causality, including a tiered basis that exists in the model mechanism. Specifically, this study is also a correlational study that aims to see the symptom of the relationship and the level of the relationship between two or more variables.

The effect of causality in this study is the relationship between good regional trust and alliances performance, the relationship between competence trust and alliances performance, the relationship between resource sharing (Tangible and Intangible) and alliances performance, the relationship between Resources Sharing as a mediating 
variable between good regional trust and competence trust with alliances performance. Because this research uses primary data where data collection is done using instruments, the data collection technique is done by conducting interviews with several combinations, either using a face-to-face approach, filling out a questionnaire.

PLS is an alternative approach to SEM (path analysis based) which is used for predictive purposes and theory development while SEM (covariance based) is more intended for theoretical testing and is confirmatory (Andreev, 2013). Even so, in further development PLS is also widely used in research oriented to testing hypotheses and is confirmatory (Gaston, 2013). So that the PLS testing process can be used to estimate the presence or absence of relationships and propositions in a test (Sofyan, Yamin and Heri Kurniawan, (2011). PLS analysis has advantages in terms of criteria and a more flexible statistical interpretation, such as not emphasizing certain assumptions, being able to predict models based on less solid theory, being able to estimate parameters consistently increasing according to the number of samples, being able to process less ideal data in the case of the cyclic sum test (data does not need to be generally distributed because PLS has nonparametric characteristics, problems related to multicollinearity and auto correlational), can process small sample data, can increase statistical strength through the convergence of more data, analyze models with high complexity and construct testing reflective and formative (Sarstedt, Ringle, Smith, Reams, \& Hair, 2014). With this variety of flexibility, Monecke and Leisch (2012) state that PLS is a soft modeling technique (Soft - Modeling Technique). Therefore, model evaluation in PLS is carried out by evaluating the Outer model and the inner model.

\section{RESULT AND DISCUSSION}

In this study, researchers used Partial Least Square Modeling (PLS Modeling), while the data analysis process used the First Order Analysis (FOA) approach. In some literature regarding relevant research, many use the approach (FOA) by combining each subdimension and indicator in it into one measurement dimension/construct (Lauksen, Nagy, Hirvonen, Reijonen, and Pasanen 2013).

FOA modeling is shown in the image below. In the figure, after testing the validity of the model, it appears that the alliance's performance variable is measured by 7 (seven) items, 
the variable Goodwill Trust is measured by 4 (four) items, the competence trust variable is measured by 4 (four) items, the variable Tangible $\&$ Intangible resources shared are calculated by 9 (nine).

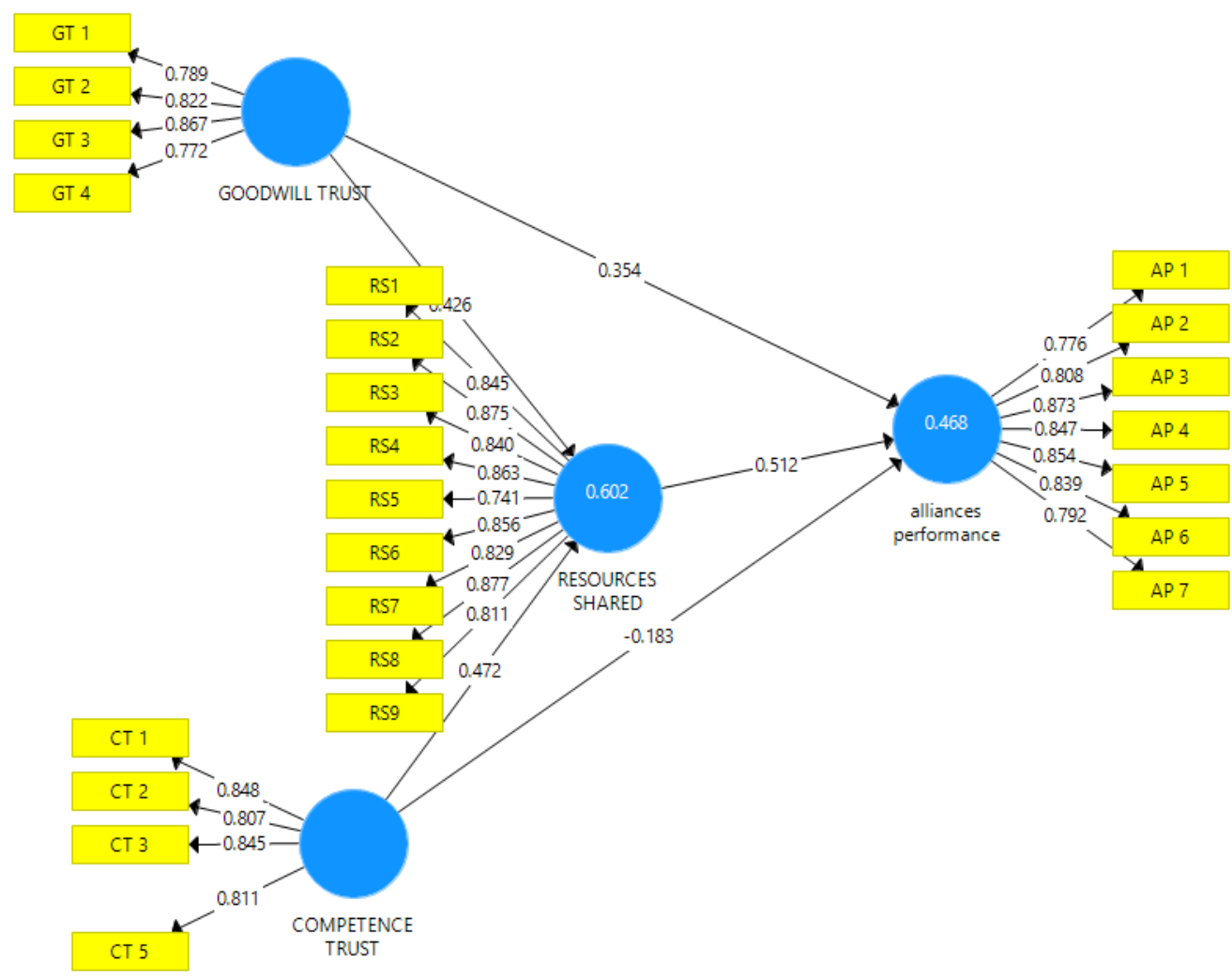

Figure 2. Research Structural Equation Model - First Order (Full Model)

In PLS analysis, the discriminant validity test is carried out by comparing each construct's AVE roots with other constructs in the model being tested. A model is said to have sufficient discriminant validity if the AVE roots for every other construct in the model (Chin, Gopal, \& Salisbury, 1997). In general, the validity test parameters in PLS measurements are shown in the table below (Chin, 1995) in Jogiyanto and Abdillah (2009).

Table 2. Validity Test Parameters in the PLS Measurement Model (Chin, 1995 in Jogiyanto and Abdillah, 2009) 


\begin{tabular}{|c|c|c|}
\hline Uji Validitas & Parameter & Nilai \\
\hline \multirow{2}{*}{ Konvergen } & Faktor loading & Lebih dari 0.7 \\
\cline { 2 - 3 } & Average Variance Extracted & Lebih dari 0.5 \\
\cline { 2 - 3 } & Communality & Lebihdari 0.5 \\
\cline { 2 - 3 } & Aksar AVE dan & AKar AVE > Korelasi \\
& KorelasiVariabelLaten & Variabel Laten \\
\cline { 2 - 3 } & Cross Loading & Lebih dari 0.7 dalam \\
& & satu variabel \\
\hline
\end{tabular}

Overall, two techniques in determining discriminant validity have provided results that meet the criteria for discriminant validity. However, there are statistical problems in the reality of convergence with item correlation. The value of one item is less than 0.7 , so it is necessary to cut off the value that is still not acceptable.

The picture above shows that 5 (five) items are omitted into 4 (four) things for competence trust items. So that it affects the assessment of the other correlation values of each item. However, overall for articles on other variables, it is still not very influential; this is evidenced by each item's correlation value at a value of $>0.7$. So that only 1 item is cut off because it has a value of $<0.7$.

Table 3. Evaluation of the structural model - Interaction effects of the path coefficient

\begin{tabular}{|l|c|c|c|c|c|}
\hline & $\begin{array}{c}\text { Original } \\
\text { Sample (O) }\end{array}$ & $\begin{array}{c}\text { Sample } \\
\text { Mean (M) }\end{array}$ & $\begin{array}{c}\text { Standard } \\
\text { Deviation } \\
\text { (STDEV) }\end{array}$ & $\begin{array}{c}\text { T Statistics } \\
(\mid \mathbf{O} / \text { STDEV|) }\end{array}$ & $\begin{array}{c}\text { P } \\
\text { Values }\end{array}$ \\
\hline $\begin{array}{l}\text { COMPETENCE } \\
\text { TRUST -> } \\
\text { RESOURCES } \\
\text { SHARED }\end{array}$ & 0,472 & 0,496 & 0,088 & 5,391 & $\mathbf{0 , 0 0 0}$ \\
\hline $\begin{array}{l}\text { COMPETENCE } \\
\text { TRUST - }\end{array}$ & $-0,183$ & $-0,186$ & 0,092 & 1,990 & $\mathbf{0 , 0 4 7}$ \\
\hline
\end{tabular}




\begin{tabular}{|l|c|c|c|c|c|}
\hline $\begin{array}{l}\text { >ALLIANCES } \\
\text { PERFORMANCE }\end{array}$ & & & & & \\
\hline $\begin{array}{l}\text { GOODWILL } \\
\text { TRUST -> } \\
\text { RESOURCES } \\
\text { SHARED }\end{array}$ & 0,426 & 0,408 & 0,111 & 3,853 & $\mathbf{0 , 0 0 0}$ \\
\hline $\begin{array}{l}\text { GOODWILL } \\
\text { TRUST - } \\
>\text { ALLIANCES } \\
\text { PERFORMANCE }\end{array}$ & 0,354 & 0,372 & 0,090 & 3,948 & $\mathbf{0 , 0 0 0}$ \\
\hline $\begin{array}{l}\text { RESOURCES } \\
\text { SHARED - } \\
\text { >ALLIANCES } \\
\text { PERFORMANCE }\end{array}$ & 0,512 & 0,506 & 0,101 & 5,060 & $\mathbf{0 , 0 0 0}$ \\
\hline
\end{tabular}

Goodwill trust in alliance performance where T statistics' value is 3,948 and P-value is 0,000 , which proves that the first hypothesis shows significant results. The first hypothesis test shows that the goodwill trust variable has a positive and significant effect. Thus it can be concluded that the research hypothesis $\mathrm{H} 0$ is accepted.

This condition is following According to Roy, Sivakumar, \& Wilkinson (2004) in (Jiang et al., 2015) in a study of manufacturing companies in China, which suggests that goodwill trust tends to facilitate cooperative relations and thus directly improves the performance of the alliance. When perceived a higher level of trustworthiness in goodwill, the alliance firms are more likely to value interactions in the partnership and interact more frequently. This is also reinforced by (Zaheer et al., 1998) that goodwill trust tends to reduce the scope, intensity, and frequency of dysfunctional conflicts, minimizing compliance and cost coordination, ultimately improving alliance performance.

Competence trust in Alliances Performance where the value of T statistics is 1.990 and $\mathrm{P}$-value is 0.047 . The second hypothesis test shows that the competence trust variable has a positive and significant effect. Thus it can be concluded that the research hypothesis $\mathrm{H} 0$ is accepted. This is in line with research by Patzelt \& Shepherd (2008) that with a high level of competency trust alliance, according to managers, it is assumed that partners can meet expectations. Therefore, the alliance's current bad performance is more likely to be associated with exogenous anomalies than partners. To the extent that the manager views 
this exogenously as temporary, he will believe that joint efforts with competent partners and alliance goals can be achieved.

Thus, although the current alliance may appear below the aspirations that managers had when the alliance was initiated, managers can quickly adjust their aspirations to their current low-performance state (Greve, 2002) and 'up' what is believed to be a temporary decline in performance. The likelihood that the alliance manager decides to stick with the alliance's poor performance may increase with more significant confidence incompetence. This shows that there is a relationship between Competence Trust and alliance performance.

Tangible \& Intangible Resources Shared to Alliances Performance has a statistical T value of 5.060 and a $\mathrm{P}$ value of 0.000 ; this proves that the third hypothesis shows significant results because the P-value is smaller than 0.005 while the statistical $\mathrm{T}$ is greater than the standard deviation. According to (Jiang et al., 2015), research on manufacturing companies in China found that the division of (a) tangible and (b) intangible resources has a positive effect on alliance performance. This is also reinforced by (Chang 2008) that scholars take advantage of a resource-based view and find that resource sharing between strategic business units (SBUs) positively affects firm performance.

Goodwill trust intangible \& intangible resources shared with a T statistical value of 3.853 and a $\mathrm{P}$ value of 0.000 , indicating a significant value. The fourth hypothesis test shows that the Goodwill Trust variable positively and significantly affects Tangible \& Intangible Shared Resources and Intangible Resources Shared. Ndofor, Sirmon, \& He (2011) found evidence that good faith-based trust is positively related to increasing information sharing in supplier-buyer relationships. Then according to Galbreath (2005) that relatively simple communication mechanisms involving written documents and private conversations can be guaranteed by the trust that goodwill is sufficient to share real resources. As such, we argue that the trust in goodwill will facilitate resource sharing. Competence trust for tangible \& Intangible resources shared, the value of $\mathrm{T}$ statistics is 5.014, and P-value of 0.000 is a significant value. It shows that the Competence Trust variable has a positive and significant influence on Tangible Resources Shared and Intangible Resources Shared. According to Krause, Handfield, \& Tyler (2007), with 
higher competency levels of trust, alliance firms are more likely to share valuable resources with each other because they believe that their partners can utilize resources to create synergies. It is made clear by Jiang et al. (2015) that companies will expect that partners they believe are competitors who are not only able to share valuable resources effectively, they are also able to increase shared resources to create shared value and increase the efficiency of the alliance. According to Jiang et al. (2015), in a study of manufacturing companies in China, they found that the sharing of intangible resources is more substantial with trust competencies than sharing tangible resources. It is made clear by Hitt (2001) that competency beliefs tend to be more effective for intangibles than for sharing tangible resources. In particular, given their complex nature to move, intangible resources appear to be more susceptible to uncertainty and error when shared. Then Jiang et al. (2015) also explain more fully that the two interactions arise from competency beliefs and the ability-based nature of competency confidence encourages a more intangible sharing of resources.

Table 4. Evaluation of the structural model - The interaction effect of the indirect path coefficient

\begin{tabular}{|l|c|c|c|c|c|}
\hline & $\begin{array}{c}\text { Original } \\
\text { Sample } \\
(\mathbf{O})\end{array}$ & $\begin{array}{c}\text { Sample } \\
\text { Mean } \\
(\mathbf{M})\end{array}$ & $\begin{array}{c}\text { Standard } \\
\text { Deviation } \\
(\text { STDEV })\end{array}$ & $\begin{array}{l}\text { T Statistics } \\
(\mid \mathbf{O} / \text { STDEV })\end{array}$ & $\begin{array}{c}\text { P } \\
\text { Values }\end{array}$ \\
\hline $\begin{array}{l}\text { COMPETENCE } \\
\text { TRUST -> } \\
\text { RESOURCES -> } \\
\text { SHARED }\end{array}$ & 0,242 & 0,253 & 0,075 & 3,229 & $\mathbf{0 , 0 0 1}$ \\
$\begin{array}{l}\text { ALLIANCES } \\
\text { PERFORMANCE }\end{array}$ & & & & & \\
\hline $\begin{array}{l}\text { GOODWILL -> } \\
\text { TRUST -> } \\
\text { RESOURCES } \\
\text { SHARED } \\
\text { ALLIANCES } \\
\text { PERFORMANCE }\end{array}$ & 0,218 & 0,203 & 0,063 & 3,487 & $\mathbf{0 , 0 0 1}$ \\
\hline
\end{tabular}

Goodwill trust through Tangible \& Intangible Resources Shared to alliances performance T statistical value of 3.487 and P-value of 0.001 indicates a significant value. This is in line with Gulati \& Singh's research in Krishnan, Rekha (Simon Fraser University, 
Burnaby, BC et al., (2006) that the degree of interdependence in alliances increases with the importance and extent of resources shared between partners and with overlaps. It is resulting in the division of labor between them (i.e., shared responsibility generated for a number of tasks), whereas the alliance that is defined as sharing production facilities usually only has a weak interdependence effect or, in other words, that the positive relationship between trust and the alliance's performance is more substantial in an alliance with a high level of interdependence rather than an alliance with low interdependence (Krishnan, Rekha (Simon Fraser University, Burnaby, BC et al., 2006). So we can conclude that the effect of trust on the performance of the alliance depends on the level of resource sharing carried out.

Competence trust through Tangible \& Intangible Resources Shared to alliances performance with a T statistical value of 3.229 and P-value of 0.001 indicates a significant value. The seventh hypothesis test shows that the Competence trust variable has a positive and significant effect through Tangible \& Intangible Resources Shared on alliances performance. In other words, Tangible \& Intangible Resources Shared as an intervening variable can mediate between Competence trust and alliance performance.

According to Jiang et al. (2015), trust (goodwill and competence) and sharing of resources (tangible and intangible), as well as sharing resources and alliance performance. It can be concluded that the path from trust to alliance performance may also be indirect. In particular, trust only establishes the basis for a superior alliance outcome. Meanwhile, it is through sharing tangible and intangible resources that the value of faith can be fully realized for the alliance company.

\section{CONCLUSION}

Based on the results of data processing and analysis of the comprehensive research data, the conclusion that can be obtained is that all tested hypotheses are acceptable. Goodwill trust has a significant influence on the strategic alliance's performance so that if the trust of goodwill is higher, the performance of the alliance strategy is higher. Competence trust also has a significant influence on the performance of the alliance strategy. So that if the competence trust is higher, the alliance strategy performance will be higher. Including tangible \& Intangle resource sharing influences the performance of the alliance strategy. 
As well as being able to mediate goodwill trust and competence trust in the performance of the alliance strategy.

So it can be concluded that the alliance strategy service company with the best performance depends on goodwill belief, competence, tangible and intangible resources sharing. To get a good alliance strategy performance, the company must ensure goodwill, trust, and competence with partners are well maintained. At the same time, companies must share tangible \& intangible resources with partners according to their needs and agreements to increase partner trust in this alliance.

Based on the results of data processing and analysis of the comprehensive research data, the advice that can be given from the results of this research is that research can be carried out by testing and adjusting the same model by researching research objects of services or other actual products. Conducting research with a broader scope in the Jakarta area and in different regions in Indonesia to reflect the performance conditions of other alliances so that the standard performance standards for the best alliance strategies are met in each region.

The academics implications of this research based on previous research conducted by Jiang, Jiang, Cai, \& Liu, (2015) on Chinese manufacturing companies, it shows that all variables have a positive influence on alliance performance. Likewise in this study all variables have a positive relationship to alliances performance. In this study, although it is a new form adapted from previous research where resources sharing is not divided, it is still combined. Due to differences in the object of research and the area under study. In this study, using the object of research from one of the educational service companies, namely Kumon in the Jakarta area. Based on the object of research carried out, namely service companies when compared with real product research objects have the same results and have a significant positive relationship with alliaces performance. Besides, this research can allow alliances performance to be combined with others both on the object of real product research or services that can be adapted to current conditions.

The managerial implications of this research include findings that are useful for the performance of alliances or alliances performance of Kumon tutoring based on the results of discussion and research analysis. First, the results of the study indicate that the Alliances performance model for service business alliances has the same and positive 
results both in manufacturing and business in real products. This is evidenced by the fact that all variables have a positive result on the alliances performance. Where in this study there are variables Tangible \& Intanguble Resources shared which in the previous study were separated but by the researcher combined as a form of adjustment to the previous research theoretical framework. It turns out to have a positive effect on the alliance's performance. So this proves that the tangible resources shared side of the service company does not affect the performance of the alliance positively. So that research on the performance of the alliance can provide additional different understanding of service products and real products. Second, the findings of this study indicate that in service products to provide a good alliance performance, in addition to maintaining trust or trust, it also ensures that tangible \& intangible resources are shared in the eyes of business partners. Third, for those who own the Kumon tutoring franchisee, they can pay attention that to build a good alliance performance, placing trust in both goodwill trust and competence trust and tangible \& intangible resources shared is the main thing so that the alliance is maintained.

\section{References}

Abdillah., W dan Jogiyanto. 2009. Partial Least Square (PLS) Alternatif SEM Dalam Penelitian Bisnis . Penerbit Andi: Yogyakarta. Hal 262.

Andreev, P. (2013), Imlementation of Partial Least Square (PLS) Modelling in Economics and Business Management Research. BEROC University of Ottawa Telfer School of Management. $1-90$.

Barney, J. (1991). Firm Resources and Sustained Competitive Advantage. Journal of Management, 17(1), 99-120.

Baum, J. A. C., Tony, C., \& Silverman, B. S. (2000). Don' t Go It Alone: Alliance Network Composition and Startups 'Performance in Canadian Biotechnology Author ( s ): Joel A . C . Baum, Tony Calabrese and Brian S . Silverman Stable. Strategic Management Journal, 21(3), 267-294.

Brattström, A., Löfsten, H., \& Richtnér, A. (2012). Creativity, trust and systematic 
processes in product development. Research Policy.

Chang, S. J. (2008). of Group-Af' Hilia' Ted Economic Performance Companies in Korea: Intragroup Resource Sharing and Internal Business Transactions. Management, 43(3), 429-448.

Chin, W. W., Gopal, A., \& Salisbury, W. D. (1997). Advancing the Theory of Adaptive Structuration: The Development of a Scale to Measure Faithfulness of Appropriation. Information Systems Research, 8(4), 342-367.

Cooper, Donald R.C. dan Emory, William. (1998). Metode Penelitian Bisnis. Erlangga, Jakarta

Das, T. K., \& Teng, B. S. (2000). A resource-based theory of strategic alliances. Journal of Management, 26(1), 31-61.

Dyer, J., \& Chu, W. (2011). The determinants of trust in supplier-automaker relations in the US, Japan, and Korea: A retrospective. Journal of International Business Studies, 42(1), 28-34.

Dyer, J. H., \& Chu, W. (2003). The Role of Trustworthiness in Reducing Transaction Costs and Improving Performance: Empirical Evidence from the United States, Japan, and Korea. Organization Science.

Eisenhardt, K. M., \& Schoonhoven, C. B. (1996). Resource-based View of Strategic Alliance Formation: Strategic and Social Effects in Entrepreneurial Firms. Organization Science, 7(2), 136-150.

Finance, C., \& Number, S. (2006). McKinsey on Finance. Corporate Finance, 32(32), 516.

Galbreath, J. (2005). Which resources matter the most to firm success? An exploratory study of resource-based theory. Technovation, 25(9), 979-987.

Green, R. (2003). Measuring goodwill trust between groups of people: three years of an oil industry alliance. Strategic Change, 12(7), 367-379.

Hitt, M. A. (2001). Direct and Moderating Effects of Human Capital on Strategy and 
Performance in Professional Service Firms : A Resource-Based Perspective Author ( s ): Michael A. Hitt, Leonard Bierman, Katsuhiko Shimizu and Rahul Kochhar Source : The Academy of Manageme. Academy of Management Journal, 44(1), 1328.

Hu, S., \& Bettis, R. A. (2014). Adaptive Aspirations and Performance Heterogeneity: Attention Allocation Among, 637(February 2012), 617-637.

Henseler, J. (2017a). Bridging design and behavioral research with variance-based structural equation modeling. Journal of Advertising, 46(1), 178-192.

Jain, M., Khalil, S., Johnston, W. J., \& Cheng, J. M. S. (2014). The performance implications of power-trust relationship: The moderating role of commitment in the supplier-retailer relationship. Industrial Marketing Management, 43(2), 312-321.

Jiang, X., Jiang, F., Cai, X., \& Liu, H. (2015). How does trust affect alliance performance? The mediating role of resource sharing. Industrial Marketing Management, 45(1), $128-138$.

Kinderis, R., \& Jucevičius, G. (2015). Strategic Alliances - Their Definition and Formation. Latgale National Economy Research, 1(5), 106.

Krause, D. R., Handfield, R. B., \& Tyler, B. B. (2007). The relationships between supplier development, commitment, social capital accumulation and performance improvement. Journal of Operations Management, 25(2), 528-545.

Krishnan, Rekha (Simon Fraser University, Burnaby, BC, C., Martin, Xavier. (Tilborg University, Tilburg, N., \& Noorderhaven, Niels G. (Tilborg University, Tilburg, N. (2006). When Does Trust Matter To Alliance Performance? Academy of Management Journal, 49(5), 894-917.

Lansing, E., Collins, F., \& Wiley, J. (2007). Research notes and commentaries toward greater understanding of market orientation and the resource-based view. Strategic Management Journal, 28(5), 961-964.

Lasserre, P. (2012). Strategic Alliances. Global Strategic Management, (August 2007), 
$1-27$.

Lee, K. H., \&Chen , S. H. (2013). Introduction to Partial Least Square: Common Criteria and Practical Considerations. Advanced Material Research, 779-780, 1766-1769

Levin, D. Z., Cross, R., \& Abrams, L. C. (2002). the Strength of Weak Ties You Can Trust: the Mediating Role of Trust in Effective Knowledge Transfer. Academy of Management Proceedings, 2002(1), D1-D6.

Lewis, J. D. (1985). Trust as a Social Reality , Social Forces, 63:4 (1985:June) p.967, 4(1), 967-985.

Li, W., \& Veysel, Y. (2013). Research on relationship between goodwill trust, competence trust and alliance performance - Based on analysis on the moderating role of potential competition between partners. Proceedings of 2013 6th International Conference on Information Management, Innovation Management and Industrial Engineering, ICIII 2013, 2, 569-573.

Location, N., \& Formation, A. (2015). and Learning: the Network Location of Network Resources and Firm Influence on Alliance Capabilities, 20(5), 397-420.

Lópezlira, D. (2015). Migraciones forzadas por cambio climático: Tabasco como caso de estudio, 19(0350), 43.

Lui, S. S., \& Ngo, H. yue. (2004). The role of trust and contractual safeguards on cooperation in non-equity alliances. Journal of Management, 30(4), 471-485. https://doi.org/10.1016/j.jm.2004.02.002

Lumineau, F., \& Malhotra, D. (2011). Trust and collaboration in the aftermath of conflict: the effects of contract structure. Academy of Management Journal, 54(5), 981-998.

McCutchen, W. W., Swamidass, P. M., \& Teng, B. S. (2007). Strategic alliance termination and performance: The role of task complexity, nationality, and experience. Journal of High Technology Management Research, 18(2), 191-202.

Mohr, A. T., \& Puck, J. (2013). Revisiting the Trust-performance Link in Strategic Alliances. Management International Review, 53(2), 269-289. 
Monecke, A. \&Leisch, F. (2012). semPLS: structural equation modeling using partial least squares. Journal of Statistical Software, 48 (3), 1-32.

Ndofor, H. A., Sirmon, D. G., \& He, X. (2011). Firm resources, competitive actions and performance: Investigating a mediated model with evidence from the in-vitro diagnostics industry. Strategic Management Journal, 32(6), 640-657.

Paik, Y. (2005). Risk management of strategic alliances and acquisitions between Western MNCs and companies in central Europe. Thunderbird International Business Review, 47(4), 489-511.

Patzelt, H., \& Shepherd, D. A. (2008). The decision to persist with underperforming alliances: The role of trust and control. Journal of Management Studies, 45(7), $1217-$ 1243.

Powell, W. W., Koput, K. W., \& Smith-Doerr, L. (2006). Interorganizational Collaboration and the Locus of Innovation: Networks of Learning in Biotechnology. Administrative Science Quarterly, 41(1), 116.

Publications, S. (2019). Determinants of Long-Term Orientation in Buyer-Seller Relationships. Journal of Marketing, 58(2), 1-19.

Rempel, J. K., \& Holmes, J. G. (1989). Trust in close relationships. Close relationships. Review of personality and social psychology, 10(1), 187-220.

Sarstedt, M., Ringle, C. M., Smith, D., Reams, R., \& Hair, J. F. (2014). Partial least squares structural equation modeling (PLS-SEM): A useful tool for family business researchers. Journal of Family Business Strategy, 5(1), 105-115.

Shackman, J.D. (2013). The Use of Partial Least Squares Path Modelling and Generalized Structured Component Analysis In International Business Reserch A Literature Review. International Journal of Management, 30(3) (1), 78-85

Sanchez, G. (2013). PLS Path Modellling with R. Trowchez Editions: Barkley

Sugiyono. 2002. Metode Penelitian Administrasi. Bandung : CV Alfabeta.

Senguin, A. E., \& Wasti, N. S. (2007). Trust, Control, and Risk. Group \& Organization 
Management, 32(4), 430-465.

Shah, R. H., \& Swaminathan, V. (2008). Factors influencing partner selection in strategic alliances: The moderating role of alliance context. Strategic Management Journal, $29(5), 471-494$.

Shou, Z., Guo, R., Zhang, Q., \& Su, C. (2011). The many faces of trust and guanxi behavior: Evidence from marketing channels in China. Industrial Marketing Management, 40(4), 503-509.

Stoltz-andersen, P. A. (2014). Hvad er Folkebevægelsen mod Ensomhed? Journals.Aom.Org, 30(1), 146-165.

Sofyan, Yamin dan Heri Kurniawan, (2011), "Generasi Baru Mengolah Data Penelitiandengan partial Least Square Path Modeling”, Jakarta: Penerbit Salemba Infotek.

Tenenhaus, M., Vinzia, V., Chatelin, E., dan Lauro, C. 2005. "PLS Path Modeling Computationa Statistic dan Data Analysis", 48: 159-205.

Tavakol, M .Denick, R. (2011). Making Sense of Croanbach's Alpha. International Journal of Medical Education, 2, 53-55

Van Wijk, R., Jansen, J. J. P., \& Lyles, M. A. (2008). Inter- and intra-organizational knowledge transfer: A meta-analytic review and assessment of its antecedents and consequences. Journal of Management Studies, 45(4), 830-853.

Vatne, E. (2017). Alliances and Franchises. International Encyclopedia of Geography: People, the Earth, Environment and Technology, 1-7.

Whipple, J. M., Frankel, R., \& Daugherty, P. J. (2002). Information Support for Alliances: Performance Implications. Journal of Business Logistics, 23(2), 67-82.

Wittmann, C. M., Hunt, S. D., \& Arnett, D. B. (2009). Explaining alliance success: Competences, resources, relational factors, and resource-advantage theory. Industrial Marketing Management, 38(7), 743-756.

Yan, A., \& Gray, B. (1995). Bargaining Power, Management Control, and Performance 
in U.S.-China Joint Ventures: A Comparative Case Study. International Joint Ventures: Economic and Organizational Perspectives, 37(6), 91-125.

Zaheer, A., McEvily, B., \& Perrone, V. (1998). Does Trust Matter? Exploring the Effects of Interorganizational and Interpersonal Trust on Performance. Organization Science, 9(2), 141-159. 